added:- " All this is the roughest possible, but I think if worked out in detail the result would not be widely different. The greatest care would, of course, be necessary to guard against submarine explosives." To this letter Sir John Burgovne replied that he doubted whether 5 inches of iron would answer its intended purpose and make a vessel practically impregnable. In this connection he remarked:- "Iron is very treacherous, and breaks, rends, and tears under very irregular effort. The Navy have a thorough dislike to it for the sides of ships, but then they have never contemplated, I believe, such thicknoss."

These remarks from so high an authority on ordnance as Sir John Burgovne throw an interesting light upon opinions prevailing little more than fifty years ago in regard to naval construction. Lord Rosse was not discouraged, but proceeded to press his scheme upon the attention of the Duke of Newcastle and on Sir Baldwin Walker, who was then Controller of the Navy. In his letter to the Duke of Newcastle, Lord Rosse stated that he " had been considering, no doubt in common with many others, in what way the great mechanical resources of England could be brought to bear against the mechanical resources of St. Petersburg." In thus writing, Lord Rosse no doubt had in view the fact that ironclad floating batteries had been decided upon. Five such vessels were commenced in France in September, 1854 , and later on similar vessels were built here, but not from Lord Rosse's outline design.

In the publication of these letters a filial duty has been fulfilled. The late Lord Rosse is shown to have been one of the first to make a definite proposal for the construction of ironclad floating batteries, and his treatment of the subject is worthy of his scientific reputation. On the other hand, it cannot be doubted that the action taken in France was independent of the suggestions of the late Lord Rosse. The correspondence with Sir John Burgoyne, the Duke of Newcastle and others could not have been known to the Emperor Napoleon when he took action; the construction of the French floating batterjes was commenced about the same time as these letters were written, but was preceded by experimental trials madc to determine the thickness of the armour to be adopted. It may be added that General Paixhans, to whom the introduction of horizontal shell-fire was due, had proposed the use of armour protection for ships about 1820 , and $\mathrm{Mr}$. Stevens began the construction of a floating battery near New York many years before the Crimean War took place. Lord Rosse obviously had no knowledge of these facts when he made the proposals above described, and acted quite independently.

\section{THE SMITHSONIAN INSTITUTION.}

THE report of the secretary of the Smithsonian Institu1 tion for the year ending June 30 , 1907 , has been
received. It serves admirably to show the great part taken by the institution in American scientific life. Full particulars are provided, not only of the explorations and researches inaugurated by the institution, but also of the work of the U.S. National Museum the Bureau of American Ethnology, the International Exchanges, the National Zoological Park, the Astrophysical Observatory, the Regional Bureau of the International Catalogue of Scientific Literature, and the excavations on the Casa Grande Reservation-ail placed by Congress under the direction of the institution.

Reference has already been made from time to time in these pages to the researches prosecuted in connection with the institution, but it will be of interest to refer to a few which are summarised in the report. In connection with the study of the older sedimentary rocks of North America, on which Dr. Charles D. Walcott, the secretary of the institution, has been engaged during the past twenty years, upwards of 20,000 fect of strata have been carefully examined and measured. The Cambrian section has been found to include more than 12,000 feet of sandstones, shales, and limestones, and the Lower, Middle, and Upper Cambrian have been found represented in the section of Bow River series and the Castle Mountain group. Characteristic fossils have been found in each division.
An expedition in April, 1907, to Alaska to collect the remains of large extinct vertebrates, particularly mammals, has already done good work. Dr. G. P. Merrill has cxamined the crater-form depression near Canyon Diablo, Arizona, to determine whether it was caused by explosive volcanic action or is due to the impact of a mass of meteoric iron; his observations are being collated and arranged.

In connection with the seismological investigations undertaken to compare the disturbance in Chile with that in California, it seems to have been determined that there has been some elevation of the coast of Chile, but no traces of a rift such as caused the earthquake at San Francisco. Numerous other researches were assisted during the year: these included the absolute measure of sound, the properties of matter at very low temperatures, the study of the upper air, the organs of flight, and others.

\section{UNIVERSITY AND EDUCATIONAL INTELLIGENCE.}

Cambridge. - The council of the Senate recommends that the necessary steps be taken for altering Statute B, chapter vi., by the insertion of a paragraph giving the University power, upon the retirement of a professor, either at the date of his retirement or subsequently, to appoint him as a professor emeritus in the subject of the professorship previously held by him. A professor emeritus shall not as such receive any stipend, and shall be subject to no conditions as to duties or residence.

Dr. W. N. Shaw, of Emmanuel College, has been appointed to represent the University at the meeting of Imperial and colonial metcorologists, convened by the Royal Soriety of Canada, to be held at Ottawa in May.

Mr. J. S. Gardiner has been re-appointed demonstrator in animal morphology for five years as from October 1 , 1907, and the appointment has been approved by the special board for biology and geology.

The special board for biology and geology reports that the Gordon Wigan income for biology and geology has been applied during 1907 as follows:- (a) a grant of $50 \mathrm{l}$. a year to Dr. D. Sharp for a period of threc years (1907-9), or such part of it during which he holds the curatorship in zoology; $(b)$ a grant of $50 l$. a year for one year (190 7$)$ to Prof. Seward to enable the Botanic Gardens Syndicate to offer greater facilities for plant-breeding experiments; (c) a grant of $50 l$. out of the income for 1907 to Prof. Hughes, to enable Mr. E. A. N. Arber, of Trinity College, to continue his researches into the stratigraphical and geographical distribution of fossil plants.

Lord Stanley of Alderley will distribute the prizes and certificates to evening students of the Battersea Polytechnic on Wednesday evening, February 19, and will deliver an address.

We learn from the Pioneer Mail that the Maharaja of Darbhanga has made a gift of nearly $17,000 l$. to the Lieutonant-Governor for the purpose of constructing a library building in connection with the Calcutta University.

THF annual general meeting of the Association of Technical Institutions will be held on February $2 \mathrm{I}$ and 22 at the Drapers' Hall, Throgmorton Street, London. On the first day the association will be entertained at luncheon by the Drapers' Companv, after which the new president, Sir Norman Lockyer, K.C.B., F.R.S., will deliver his presidential address. On the second day papers will be read on the best early training for a boy about to enter a technical institution or to take up a trade.

IN a recent report, the Director of Education for the United Provinces has, in accordance with the orders of the Government of India, described the progress of education in his district during the last five years. An abridgment of the report in the Pioneer Mail states that the attendance at the Thomason Civil Engineering College at Roorkee has increased from 336 to 495 , and various improvements in and extensions of the curriculum have been effected. An agricultural college has been opened at Cawnpore. It is hoped that the medical college at Lucknow will be in working order soon. The Thomason College will, it is 